\title{
The Impact of Using Social Media on Dental Treatment: An Online Survey
}

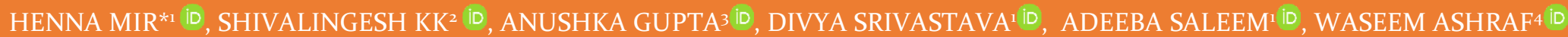

INTRODUCTION: Social media is a mode of communication that allows a person to create and share information with others.

Facebook, WhatsApp, Twitter, Google+, YouTube etc are some examples of social media applications and they allow people to communicate across the world. There is very less literature available that shows the effect of social media in esthetics in India.

AIM: To conduct an online survey to see the impact of using social media on esthetic dental treatments.

MATERIALS AND METHOD: 477 questionnaires were returned with responses and the data was entered into the MS excel sheet. Descriptive statistics was used for the frequency distribution and Chi Square was applied for the statistical relationship between male and female variables (at 5\% significance).

RESULTS: Four hundred seventy-seven participants responded to this study through online forms. Most of the participants belonged to the age group of $26-35$ years $(n=256)$, followed by $18-25$ years $(n=137), 36-45$ years and $>45$ years $(n=55$ \& 29 respectively). The response of females was high $(63.5 \%)$ when compared to males.

CONCLUSION: Females tend to follow dentists more as compare to males on social media. In dental practice, social media has become a widely used for exchanging and obtaining information.

KEYWORDS: Social Media, Esthetics, Survey

\section{INTRODUCTION}

Social media is a mode of communication that allows a person to create and share information with others. Facebook, WhatsApp, Twitter, Google+, YouTube etc are some examples of social media applications and they allow people to communicate across the world. ${ }^{1}$ India has 560 million active Internet users as of 2019. It is estimated that by 2021 there will be around 636 million active internet users in India. In 2021, it is estimated that there will be around 448 million social network users in India, a significant increase from 2019 where it figures at 351 million. Facebook is the most popular social networking site in the country. There are about 270 million Facebook users in India as 2019, placing India as the country with the largest Facebook user base in the world. ${ }^{2}$

The four key advantages of social media are: 1) This allows different people to collaborate 2) It allows users to create their own content through different media channels 3) It allows users to publish individual pieces of work and 4) This creates new research approaches. ${ }^{3}$ However smartphones are playing a an important role in boosting the popularity of social media. ${ }^{4}$ In addition, publishing and exchange of healthcare material encourages the use of social media as a source of information in the search for a better understanding of the differences in this field. ${ }^{5}$ It is not surprising that dentists are also showing a great interest in sharing the information and communicating with their patients through Social media. Social media is also an affordable way of publicizing a dental practice. ${ }^{6}$ It is necessary not to underestimate the power of social media and its effect on esthetic dental treatment choices. There is very less literature available that shows the effect of social media in esthetics in India. Therefore the aim of this study was to conduct an online survey to see the impact of using social media on esthetic dental treatments.

\section{MATERIALS AND METHOD}

This cross-sectional study was conducted with the help of online-electronic questionnaires from $10^{\text {th }}$ December 2019 to $10^{\text {th }}$ January 2020 after taking the ethical approval from the ethical committee of IDS Bareilly. Subjects less than 18 years of age were not included in the study. First part of the questionnaire was about the age and gender of the participants and in the second part various queries regarding the social media were asked. ${ }^{4}$ The questionnaire was constructed on Google Forms (www.docs.google.com). Five hundred questionnaires were distributed through different social media apps like WhatsApp, Facebook and 
Instagram. Reminders were given to the participants from time to time. 477 questionnaires were returned with responses and the data was entered into the MS excel sheet. Descriptive statistics was used for the frequency distribution and Chi Square was applied for the statistical relationship between male and female variables (at $5 \%$ significance)

\section{RESULTS}

Four hundred seventy seven participants responded to this study through online forms. Most of the participants belonged to the age group of 26-35 years $(\mathrm{N}=256)$, followed by $18-25$ yrs $(\mathrm{N}=137), 36-45$ years and $>45$ years $(\mathrm{N}=55 \& 29$ respectively). The response of females was high $(63.5 \%)$ when compared to males (36.0\%). (Table 1)

\begin{tabular}{|c|c|}
\hline VARIABLES & $\mathrm{n}=477$ \\
\hline Age & $137(28.7 \%)$ \\
$18-25$ yrs & $256(53.6 \%)$ \\
$26-35$ yrs & $55(11.5 \%)$ \\
$36-45$ yrs & $29(6 \%)$ \\
Above 46 yrs & $172(36.0 \%)$ \\
\hline Gender & $303(63.5 \%)$ \\
\hline Male & \\
\hline Females & 263 \\
\hline Responses from: & 145 \\
Whatsapp & 69 \\
\hline Facebook & \\
\hline Instagram &
\end{tabular}

Table 1. Demographics of the Study Participants

Table 2 shows the various opinions of the participants when they were asked different questions regarding social media. When asked whether they followed a dentist on social media, 215 (45.0\%) subjects were nonresponsive, 182 (38.1\%) of them agreed that they in-fact followed the dentist on social media, 80 (16.7\%) of them opined that they did not. Among them, females tended to follow the dentist more than males on social media and this difference was statistically significant $(\mathrm{p}=0.035)$.

Most of the participants (83.9\%) agreed that dentists should communicate with people through social media rather than conventional media (TV, newspapers, magazine) whereas $14.2 \%$ gave a negative response and very few $(1.9 \%)$ had no opinion regarding the same.

More than half of the participants (6o.8\%) responded positively when they were asked if social media was their first choice for information regarding an esthetic dental treatment or clinic, notwithstanding 33.1\% who felt otherwise and $6 \%$ did not respond to the same.

When asked about the validity of the information on social media, $56.6 \%$ of them trusted it, $38.6 \%$ of them did not and $4.8 \%$ of them were non-responsive.

The results showed us that $54.5 \%$ of the participants took their decision of choosing a dentist by their activity on social media which was not the case in $40.7 \%$ of the participants and $4.8 \%$ had no opinion regarding the same. This was particularly high among females when compared to males ( $\mathrm{p}=\mathrm{0.041})$.

Furthermore the findings revealed that $28.0 \%$ of participants narrated their dental experiences on social media while majority of them $(67.9 \%)$ did not feel it was important and $19 \%$ were non responsive.

Significant number of subjects (65.8\%) were affected by the criticism of the dentist on social media while $29.3 \%$ of them did not consider social media while choosing a dentist and $4 \%$ of them were not sure. Females were found to be more affected about the dentist's image in social media than males and the difference between them was statistically significant $(\mathrm{p}=0.023)$.

On enquiring whether their choice of dental clinic was influenced by its representation on social media, most of them (68.8\%) agreed positively, $27.3 \%$ did not agree and only $4 \%$ did not reply to this.

Similarly, before and after pictures of a dental treatment in social media was influential for $57.9 \%$ of the subjects but did not matter to $37.3 \%$ of respondents. Out of $57.9 \%$ of subjects, the difference was found to be statistically significant between males and females where females were more influenced with before and after pictures $(\mathrm{p}=0.04)$.

The findings revealed that $48.2 \%$ participants were influenced by the choice of dental treatment that a celebrity had spoken of on social media and almost same number of individuals (47\%) contrarily disagreed. Also $48.2 \%$ of respondents relied on the advertisement of cosmetic treatment which was in contrast with the $45.7 \%$ of participants who did not agree.

Majority of the participants ( $65 \%)$ were not attracted by the different offers for esthetic treatment regardless of the quality, however $30.2 \%$ of respondents were 


\begin{tabular}{|c|c|}
\hline QUESTIONS & $\begin{array}{l}\text { RESPONSES }(\%) \\
(n=477)\end{array}$ \\
\hline \multicolumn{2}{|c|}{$\begin{array}{l}\text { 1. Do you follow (dentist/dental clinic) in social } \\
\text { media? }\end{array}$} \\
\hline Yes & $182(38.2 \%)$ \\
\hline No & $80(16.8 \%)$ \\
\hline No response & $215(45.1 \%)$ \\
\hline \multicolumn{2}{|c|}{$\begin{array}{l}\text { 2. Do you think that dentists should communicate } \\
\text { with people through social media rather than } \\
\text { conventional media (TV, newspapers, magazine) }\end{array}$} \\
\hline Yes & $400(83.9 \%)$ \\
\hline No & $68(14 \cdot 3 \%)$ \\
\hline No response & $9(1.9 \%)$ \\
\hline
\end{tabular}

3. If you want to get information about an esthetic dental treatment or clinic, is social media your first choice for information?

\begin{tabular}{|c|c|}
\hline Yes & $290(60.8 \%)$ \\
\hline No & $158(33.12 \%)$ \\
\hline No response & $29(6.1 \%)$ \\
\hline
\end{tabular}

4. Do you trust the information you get from social media about dentistry and treatment options?

\begin{tabular}{|c|c|}
\hline Yes & $270(56.6 \%)$ \\
\hline No & $184(38.6 \%)$ \\
\hline No response & $23(4.8 \%)$ \\
\hline
\end{tabular}

5 . Does your decision of choosing a dentist or dental clinic affected by the activity of their account?

\begin{tabular}{|c|c|}
\hline Yes & $260(54.5 \%)$ \\
\hline No & $194(40.7 \%)$ \\
\hline No response & $23(4.8 \%)$ \\
\hline
\end{tabular}

6. Do you write about your visit to the dentist or dental clinic in social media?

\begin{tabular}{|c|c|}
\hline Yes & $134(28.1 \%)$ \\
\hline No & $324(67.9 \%)$ \\
\hline No response & $19(4 \%)$ \\
\hline
\end{tabular}

7. When you read a criticism to a dentist or dental clinic in social media, would that affect your personal decision to visit the dentist or clinic?

\begin{tabular}{|c|c|}
\hline Yes & $314(65.8 \%)$ \\
\hline No & $140(29.4 \%)$ \\
\hline No response & $23(4.8 \%)$ \\
\hline
\end{tabular}

8. Would you visit a dental clinic because you visited or read their page on social media sites?

\begin{tabular}{|c|c|}
\hline Yes & $328(68.8 \%)$ \\
\hline No & $130(27.3 \%)$ \\
\hline No response & $19(4 \%)$ \\
\hline
\end{tabular}

9. Would you go to a dentist because you saw a before and after pictures in the social media?

\begin{tabular}{|c|c|}
\hline Yes & $276(57.9 \%)$ \\
\hline No & $178(37.3 \%)$ \\
\hline No response & $23(4.8 \%)$ \\
\hline
\end{tabular}

10. If you need to get an esthetic dental treatment, is your first choice a clinic that a celebrity tried or talked about in social media?

\begin{tabular}{|c|c|}
\hline Yes & $230(48.2 \%)$ \\
\hline No & $224(47 \%)$ \\
\hline No response & $23(4.8 \%)$ \\
\hline
\end{tabular}

11. Reliance on the accuracy of the results and displays advertisements which belong to cosmetic treatment?

\begin{tabular}{|c|c|}
\hline Yes & $230(48.2 \%)$ \\
\hline No & $218(45.7 \%)$ \\
\hline No response & $29(6.1 \%)$ \\
\hline
\end{tabular}

12. Does advertisement that contain special offers for different esthetic treatment attract you, regardless of the quality of treatment?

\begin{tabular}{|c|c|}
\hline Yes & $144(30.2 \%)$ \\
\hline No & $310(65 \%)$ \\
\hline No response & $23(4.82 \%)$ \\
\hline \multicolumn{2}{|c|}{$\begin{array}{l}\text { 13. If you saw on social media a friend or family } \\
\text { member with a new smile, would you ask about } \\
\text { the esthetic dentist or dental clinic they were } \\
\text { treated in? }\end{array}$} \\
\hline Yes & $396(83.0 \%)$ \\
\hline No & $58(12.2 \%)$ \\
\hline No response & $23(4.8 \%)$ \\
\hline \multicolumn{2}{|c|}{$\begin{array}{l}\text { 14. Would you choose a dental clinic or dentist } \\
\text { based on an advertisement by a celebrity on social } \\
\text { media? }\end{array}$} \\
\hline Yes & $164(34.4 \%)$ \\
\hline No & $288(60.4 \%)$ \\
\hline No response & $25(5.2 \%)$ \\
\hline
\end{tabular}

Table 2. Responses to the Questions by the Study Participants 
attracted to the same.

Almost all $(83.0 \%)$ of the subjects would like to ask their friends or family about the esthetic dentist after seeing their pictures on social media and while very few of them (12.2\%) would not be interested in same. Females were more likely to ask as compared to males and the results were statistically significant $(\mathrm{p}=0.031)$.

\section{DISCUSSION}

Social media sites enable users to create and share information. The first social media site was created by Andrew Weinreich in 1997. Most of the people use social media for learning, marketing, shopping, decision making etc. As these new technologies grow, they have the opportunity to influence the methods and procedures of many sectors. Use of social networking sites by health care providers and patients is also growing. 4

The present study was conducted to see the impact of social media on dental treatment choices. In the present study a total of 477 subjects participated and amongst them, $303(63.5 \%)$ were females which is in agreement to the study conducted by Alnjadat et al. ${ }^{7}$ In a survey, Hanna Krasnova et al. concluded that due to their emotional volatility, females use social media platforms more than males (they like to keep close ties and gain social information) ${ }^{8}$

In the present study less than half (38.2\%) of participants were following a dentist or a dental clinic on social media which is in contrast with a study conducted by Awdah et al where 53.3\% were following a dentist on social media. ${ }^{4}$

Significant number of participants (83.9) believed that the dentist should communicate with the people through social media which was in accordance to the study conducted by Tackeray et al where the participants appreciated the social media communication of health care providers. 9 The reason for such belief was due to the fact that there would be direct communication with the dentist and the information that is passed on is credible without filtration or manipulation.

Almost $56 \%$ of the participants trusted the information regarding a dentist or a dental clinic from social media. According to Hamm et al. a high percentage of people used internet as a source of information regarding health and it is the third most common activity on internet. ${ }^{10}$ Another study conducted in 2013 by Pew Research Center shows that $72 \%$ of adult internet users found online support for medical information.11 The main reasons for using the internet were insufficient appointment time with physicians and obstacles to obtaining qualified health services. Convenience and coverage were considered to be the main advantages, while health information's credibility and trustworthiness may be the limitations.

Most of the participants in the present study (68.8\%) visited the dentist's social media page which is in contrast to a study conducted by Parmar $\mathrm{N}$ et al where a total of $64 \%(296 / 460)$ never searched their medical doctors and dentists on social media. ${ }^{12}$

In the present study females were more influenced with before and after treatment pictures $(\mathrm{p}=0.04)$ and this finding was in agreement with a study conducted by Alalawi et al where females were more interested in the positivity of reviews, before-and-after images, and the qualifications of the dentist $(\mathrm{p}<0.05) .{ }^{13}$

Majority of the participants (65.8\%) were affected by the criticism of dentist on social media which is similar to the study conducted by Awdah et al. ${ }^{4}$

In our study majority $(83 \%)$ of the participants were affected by their family or friend's dental treatment. This was in accordance with a study conducted by Fox $\mathrm{S}$ et al where $68 \%$ of all adults request health information from a friend or family member.14 These findings were also in agreement with a study conducted by Parmar $\mathrm{N}$ et al. where, patients appreciated recommendations from friends and family, for a dentist or a dental clinic. ${ }^{12}$

Very few of the participants that is $34.4 \%$ were affected by the advertisement of a dentist or a dental clinic by a celebrity on social media which was in contrast to a study conducted by Ajwa $\mathrm{N}$ et al. where $82.3 \%$ of the patients were affected by the advertisement in social media. ${ }^{15}$

\section{CONCLUSION}

Females tend to follow dentists more as compare to males on social media. In dental practice, social media has become a widely used for exchanging and obtaining information. The current findings indicate that there is a potential for dental practices to compete for increased patient interaction and involvement through a more active social media presence. 


\section{REFERENCES}

1. Bhola S, Hellyer P. The risks and benefits of social media in dental foundation training. British Dental Journal 2016;221(10):609-13.

2. https://sannams4.com/digital-and-social-medialandscape-in-india. [Last Accessed on $15^{\text {th }}$ January' 2020]

3. Andrew M, Johnston A. The Role of Social Media in Dental Education. Journal of Dental Education 2012;76(11):1474-81.

4. Awdah A, Ali B, Twaim S, Habdan A. The Power of Social Media on Esthetic Dental Treatment Choices in Arabian Gulf Region. International Journal of Dental Oral Health 2018;5(1):1-5.

5. Pereira A. Dentistry and the social media. Revista Gaucha de Odontologia 2017;65(3):230-6.

6. Makkar N, Lawrence D, Veeresh DJ, Banik A, Kumar A, Mehar SA. Journal of Indian Association of Public Health Dentistry 2018;16(3):246-50.

7. Alnjadat R, Hmaidi MM, Samha ET, Kilani M, Hasswan MA. Gender variations in social media usage and academic performance among the students of University of Sharjah. Journal of Taibah University Medical Sciences 2019;14(4):390-4.

8. Krasnova H, Veltri FN, Eling N, Buxmann P. Why men and women continue to use social networking sites: The role of gender differences. The Journal of Strategic Information Systems 2017;26(4):261-84.
9. Thackeray R, Neiger LB, Smith KA, Wagenen VS. Adoption and use of social media among public health departments. Biomed Central Public Health 2012;12(6):1-6.

10. Hamm PM, Chisholm A, Shulhan J, Milne A, Scott DS, Lisa M, et al. British Medical Journal 2013;3:1-10. 11. Fox S, Duggan M. Health online 2013. Pew Internet Am Life Proj. (Online Article). Accessed from: https://www.pewresearch.org/internet/ 2013/o1/15/health-online-2013/ [Last Accessed on $15^{\text {th }}$ January, 2020]

12. Parmar N, Dong L, Eisingerich BA. Connecting With Your Dentist on Facebook: Patients'and Dentists' Attitudes Towards Social Media Usage in Dentistry. Journal Of Medical Internet Research 2018; 20(6):e10109.

13. Alalawi A, Aljuaid H, Natto SZ. The Effect Of Social Media On The Choice Of Dental Patients: A CrossSectional Study In The City Of Jeddah, Saudi Arabia. Patient Preference and Adherence 2019;13:1685-92. 14. Fox S. The social life of health information, 2011. Pew Internet Am Life Proj. (Online Article). Accessed from: https://www.pewresearch.org /internet/2011/05/12/the-social-life-of-healthinformation-2011/[Last Accessed on $15^{\text {th }}$ January, 2020]

15. Ajwa N, Mohsen S, Kuwail A, Osaif E. The Impact of Using Social Media Networks on Dental Treatment Marketing in Saudi Arabia: The Practitioners and Patient's Perspectives. Journal of Oral Health and Dental Science 2018;2(4):1-10.

1. Post Graduate Student [ORCID IDs: https://orcid.org/oooo-0oo2-3233-2654 (Dr. Henna Mir),

https://orcid.org/oooo-0oo2-1755-8436 (Dr. Divya Srivastava), https://orcid.org/oooo-0001-6900-0613 (Dr. Adeeba Saleem)]

2. Professor \& Head (ORCID ID: https://orcid.org/oooo-0002-4636-522X)

3. Senior Lecturer (ORCID ID: https://orcid.org/oooo-0oo3-3791-1345)

Department of Public Health Dentistry, Institute of Dental Sciences, Bareilly, India

4. Post Graduate Student, Department of Oral Medicine and Radiology, Vyas Dental College, Jodhpur

(ORCID ID: https://orcid.org/oooo-0002-4828-815X) 